\title{
In vitro Toxicity Evaluation of Diesel Exhaust Particles on Human Eosinophilic Cell
}

\author{
Ryoji Hirota ${ }^{1} \cdot$ Kunihiro Akimaru $^{1}{ }^{1} \cdot$ Hiroyuki Nakamura $^{2)}$ \\ ${ }^{1)}$ Department of Environmental Medicine, Kochi Medical College \\ ${ }^{2)}$ Department of Environmental and Preventive Medicine, Kanazawa University Graduate School of \\ Medical Science \\ Corresponding author Ryoji Hirota, $\mathrm{PhD}$ \\ Address Department of Environmental Medicine, Kochi Medical College \\ Kohasu, Oko, Nankoku, Kochi 783-8505, Japan. \\ Tel. No. +81 (88) 8802407 Fax No. +81(88) 8802407 \\ E-mail hirotar@kochi-u.ac.jp
}

\begin{abstract}
:
Diesel exhaust particles (DEPs), comprised mainly of particles less than $2.5 \mu \mathrm{m}$ (PM2.5) in aerodynamic diameter, have been assumed to enhance the response of asthma to allergen inhalation. Although eosinophilic infiltration is remarkable in the event of bronchial asthma induced by DEPs, the precise mechanisms leading to eosinophilia are unknown. To examine the effect of DEPs on eosinophils, we measured the cytokine products and activity of nuclear factor -kappa B (NF- $\kappa$ B) after addition of the proteasomal inhibitor MG132 in HL-60 clone 15 cells differentiated into eosinophils. We measured eotaxin-induced chemotaxis of cells and their activity of p38 mitogen-activated protein (MAP) kinase was analyzed. Interleukin (IL)-8 and monocyte chemoattractant protein-1 (MCP-1) were increased markedly in DEPs-treated cells. The active form of NF- $\kappa$ B in cells treated with DEPs was increased, and this effect was significantly decreased by the administration of MG132. Cell migration in the presence of DEPs was significantly greater, and inhibited by adding Nacetyl L-Cysteine. P38 MAP kinase activity was highly influenced by DEPs treatment. DEPs induce MCP-1 and IL- 8 production by up-regulating NF- $\kappa$ B activity, which is inhibited in the presence of an inhibitor of proteasomal degradation. DEP also promotes eotaxin-induced chemotaxis in a $\mathrm{p} 38$-dependent manner.
\end{abstract}

Key Words :Diesel exhaust particles, monocyte chemoattractant protein-1, IL-8, eotaxin, chemotaxis

\section{Abbreviations:}

DEPs, diesel exhaust particles; MCP-1, monocyte chemoattractant protein-1;

NF- $\kappa$ B, nuclear factor -kappa B; MAP kinase, mitogen-activated protein kinase; IL-(8), interleukin-(8); NAC, N-acetyl L-cysteine; RANTES, regulated upon activation normal T cell expressed and secreted; TNF- $\alpha$, tumor necrosis factor-alpha; IFN- $\gamma$, interferongamma; FCS, fetal calf serum; PBS, phosphate buffered saline; BSA, bovine serum albumin; ATF-2, activating transcription factor-2. 


\section{Introduction}

In bronchial asthma, a marked increase in eosinophils is observed at the site of

inflammation and bone marrow. In addition, it is known that eosinophils which infiltrate the site of inflammation have in their cells a major basic protein that has cytotoxic properties. By releasing cytokines (Schmid-Grendelmeier et al., 2002), lipid mediators (Busse, 1998), reactive oxygen species (Albert et al., 2003), and highly charged cytotoxic granular proteins (Marguet et al., 2001), activated eosinophils contribute to airway inflammation and cause damage of the bronchial mucosa (Pegorier et al., 2006). Therefore, today eosinophils are thought to play a central role in enhancing inflammation.

The prevalence of allergic airway diseases such as bronchial asthma has increased in industrial areas and countries. Patients with bronchial asthma believed to be caused by air pollution are increasing, thus creating a social problem. The main components of air pollution are substances such as nitrogen oxides and ozone.

Recently, many studies have demonstrated that diesel exhaust particles (DEPs) exposure is linked to the incidence of pulmonary inflammation and allergic airway disease, particularly bronchial asthma. When a person is exposed to immunogens such as house dust and pollen after long-term exposure to polluted air which includes these fine particles, DEPs enhance inflammation in bronchial asthma (Brauer et al., 2003; Diaz-Sanchez et al., 2003; Holgate et al., 2003; Pandya et al., 2002).

The main components of DEPs are fine particles including heavy metals which are emitted from diesel engines when diesel oil combusts. These fine particles are $2.5 \mu \mathrm{m}$ or less (PM 2.5) in aerodynamic diameter and include black smoke. These fine particles contribute to the adjuvant activity of DEPs on bronchial asthma. Therefore, there are calls for the reduction of DEPs in urban areas.

Recently, many researchers have reported that inhalation of DEPs induced biologic responses to bronchial asthma (Kanoh et al., 1996) (Bloemen et al., 2007; Pandya et al., 2002). DEPs promote release of specific cytokines, chemokines, immunoglobulins, and oxidants in the airway. Release of these mediators of the allergic and inflammatory response initiates a cascade that can culminate in airway inflammation, mucus secretion, serum leakage into the airways, and bronchial smooth muscle contraction. However, it is not clear if inhalation of DEPs induced biologic response on eosinophils.

In this study, we examined the effects of DEPs on eosinophils by studying cytokine production when DEPs organic solvent extracts were given to a human leukocytic cell line HL-60 clone 15, which had been differentiated into an eosinophil-like cell line.

\section{Materials and Methods}

\subsection{Eosinophil cell culture and differentiation}

HL-60 clone 15 cells (CRL-1964, American Type Culture Collection, Rockville, MD) were maintained in RPMI-1640 medium (pH 7.8) (Sigma, St. Louis, MO) supplemented with $10 \%$ fetal calf serum (FCS) (Sigma, St. Louis, MO) and passaged twice weekly in an atmosphere of $1.5 \% \mathrm{CO} 2$. For experiments, cells $(2 \times 105$ cells $/ \mathrm{ml})$ were induced with nbutyrate ( $0.5 \mathrm{mM}$; Sigma) for 5 days (differentiated HL-60 clone 15 cells; df-HL-60 clone 15 cells), as previously described (Fischkoff, 1988) (Yamaguchi et al., 1994). Df-HL-60 clone 15 cells were assessed by morphology (eosinophil granules on May-Günwald and eosinophil peroxidase staining), previously described (Lopez et al., 2003). Peroxidase positive df-HL-60 clone 15 cells induced by n-butyric acid were collected and were used for experiments.

\subsection{Preparation of DEPs suspensions}

The DEPs suspension (National Institute for Environmental Studies, Tsukuba, Ibaraki) was prepared just prior to use. To induce particle disaggregation, stock solutions of 
particles were dispersed in phosphate buffered saline (PBS) containing $0.05 \%$ Tween 80 (Sigma Chemical, St. Louis, MO) at a concentration of $10 \mathrm{mg} / \mathrm{ml}$ and then sonicated at output 5 and duty 30 of ultrasonic disruption for 2 minutes under cooling conditions (Amakawa et al., 2003). Different concentrations of particles were then diluted with RPMI-1640. PBS containing $0.05 \%$ Tween 80 was used as a negative control in separate experiments. For cytokine array assay, DEPs $(0.03 \mathrm{mg} / \mathrm{ml})$ were treated to df-HL-60 clone 15 cells. For MCP-1 EILSA, NF-KB DNA binding assay, chemotaxis assay and p38 MAP kinase assay, DEPs $(0.1$ $\mathrm{mg} / \mathrm{ml}$ ) were treated to df-HL-60 clone 15 cells.

\subsection{Analysis of cytokines by Human Cytokine Array}

Df-HL-60 clone 15 cells $(5 \times 105$ cells $/ \mathrm{ml} ; 1 \mathrm{ml})$ in 24-well plates (Becton Dickinson Labware, Franklin Lakes, NJ) were treated with DEPs $(0.03 \mathrm{mg} / \mathrm{ml})$, IL-1 $(10 \mathrm{ng} / \mathrm{ml})$, or buffer for 72 hours at $37^{\circ} \mathrm{C}$ in $1.5 \% \mathrm{CO} 2$, and cytokines and chemokines present in the supernatant were determined using the RayBioTM Human Cytokine Array III kit (RayBiotech, Inc., Norcross, GA) following the manufacturer's instructions. According to the manufacturer, 42 different cytokines and growth factors (for example, IL-2, IL-3, IL-4, IL-5, IL-8, IL-10, IL-12, IL-13, MCP-1, tumor necrosis factor-alpha (TNF- $\alpha$ ), interferon-gamma (IFN- $\alpha$ ), regulated upon activation normal T cell expressed and secreted (RANTES) could rapidly and accurately identify the expression profiles in just one experiment by using this system. One $\mathrm{ml}$ of each sample was used for analysis. Each signal in the membrane was detected with a chemiluminescence imaging system (AE-6972 Densitograph Lumino-CCD, ATTO, Tokyo) and quantified by image analysis using a CS analyzer (ATTO, Tokyo).

\subsection{Preparation of Nuclear Extracts}

Df-HL-60 clone 15 cells (5 X 105 cells $/ \mathrm{ml} ; 20 \mathrm{ml}$ ) in $250 \mathrm{ml}$ Tissue culture flasks

(Becton Dickinson Labware, Franklin Lakes, NJ) were cultured either with or without 0.1 $\mathrm{mg} / \mathrm{ml}$ DEPs for 4 hours at $37^{\circ} \mathrm{C}$ in $1.5 \% \mathrm{CO} 2$. Untreated cells and DEPs-treated cells were harvested by centrifugation in cold PBS. Nuclear extracts were prepared according to the method described by Lee et al. (Lee et al., 1988) with modifications(Xu et al., 1997). In brief, cells were washed twice with ice-cold PBS after incubation and suspended in one packed cell volume (PCV) of buffer A (10 mM HEPES, $1.5 \mathrm{mM} \mathrm{MgCl} 2,10 \mathrm{mM} \mathrm{KCl}, 0.5 \mathrm{mM}$ dithiothreitol (DTT), $1 \mu \mathrm{g} / \mathrm{ml}$ leupeptin and aprotinin, $\mathrm{pH}$ 7.9) on ice for 10 minutes and then lysed by passing the cell suspension through a 27 -gauge needle 5 times. Crude nuclei were washed twice with buffer A to prevent cytosolic contamination, and the nuclear proteins were extracted with two-thirds PCV of ice-cold buffer B (20 mM HEPES, $420 \mathrm{mM} \mathrm{KCl}, 1.5 \mathrm{mM}$ $\mathrm{MgCl} 2,0.2 \mathrm{mM}$ ethylenediaminetetraacetic acid (EDTA), $0.5 \mathrm{mM}$ DTT, $0.5 \mathrm{mM}$ phenylmethylsulfonyl fluoride, $1 \mu \mathrm{g} / \mathrm{ml}$ leupeptin and aprotinin, and $25 \%$ glycerol, $\mathrm{pH} 7.9$ ). Two-thirds PCV of ice-cold buffer C (20 mM HEPES, $0.2 \mathrm{mM}$ EDTA, $0.5 \mathrm{mM}$ DTT, $0.5 \mathrm{mM}$ phenylmethylsulfonyl fluoride, $1 \mu \mathrm{g} / \mathrm{ml}$ leupeptin and aprotinin, $20 \%$ glycerol, $\mathrm{pH}$ 7.9) was added. The mixture was then centrifuged at $14,000 \mathrm{rpm}$ at $4^{\circ} \mathrm{C}$ for 15 minutes. The nuclear proteins were transferred to new tubes as aliquots and stored at $-70^{\circ} \mathrm{C}$ until use. The protein concentration was determined by a DC Protein Assay kit (Rio-Rad, Richmond, CA).

\subsection{NF- $\kappa B$ DNA binding assay}

$\mathrm{NF}-\kappa \mathrm{B}$ is a ubiquitous transcription factor that mediates the inflammatory response.

The proteasome inhibitor MG132 inhibits NF- $\kappa$ B formation and degradation of its inhibitor I$\kappa \mathrm{B}$. One $\mu \mathrm{g}$ of nuclear extract was used for NF- $\kappa$ B DNA binding assay. NF- $\kappa$ B activation in the nuclear extracts was quantified by an EZ-Detect NF- $\kappa$ B p65 assay kit (Pierce, Rockford, IL) based on an ELISA technique. Specifically, an immobilized oligonucleotide containing 
the NF- $\kappa$ B consensus site (5'-GGGACTTTCC-3') was bound to microwell plates. The active form of NF- $\kappa$ B present in nuclear extracts specifically binding to this oligonucleotide was detected using a primary antibody that recognizes an epitope on $\mathrm{p} 65$ that is accessible only when NF- $\kappa$ B is activated and bound to its target DNA. Then competitive oligonucleotide (wild type) of consensus site was added to the control. Following the addition of an HRPconjugated secondary antibody, the plates were read on an automated plate reader, and the level of nuclear NF- $\kappa$ B p65 was expressed as the absorbance at $450 \mathrm{~nm}$ (A450).

\subsection{Measurements of MCP-1 by ELISA}

Df-HL-60 clone 15 cells $\left(1 \times 10^{5}\right.$ cells $\left./ \mathrm{ml} ; 10 \mathrm{ml}\right)$ in $70 \mathrm{ml}$ Tissue culture flasks (Becton Dickinson Labware, Franklin Lakes, NJ) that had been preincubated with either medium or MG132 (Calbiochem, La Jolla, CA) $(5 \mathrm{nM})$ for one hour were cultured either with medium or DEPs $(0.1 \mathrm{mg} / \mathrm{ml})$ for 24 hours at $37^{\circ} \mathrm{C}$ in $1.5 \% \mathrm{CO} 2$. MCP-1 protein was measured in cultured supernatants using a commercial solid phase quantitative sandwich ELISA kit for MCP-1 (R\&D SYSTEMS, Minneapolis, MN) according to the manufacturer's descriptions.

\subsection{Chemotaxis Assay}

Df-HL-60 clone 15 cells $\left(5 \times 10^{6}\right.$ cells $\left./ \mathrm{ml} ; 5 \mathrm{ml}\right)$ were pretreated with either medium or N-acetyl L-cysteine (NAC) (Wako Pure Chemicals Ltd, Tokyo) $(5 \mathrm{mM})$ for one hour and then stimulated with human recombinant eotaxin (R\&D SYSTEMS) $(100 \mathrm{ng} / \mathrm{ml})$ for one hour at $37^{\circ} \mathrm{C}$ in $1.5 \% \mathrm{CO} 2$. After eotaxin stimulation, the cells were further stimulated with medium or DEPs $(0.1 \mathrm{mg} / \mathrm{ml})$ for one hour at $37^{\circ} \mathrm{C}$ in $1.5 \% \mathrm{CO} 2$. Cell chemotaxis was evaluated using a microchamber technique (Falk et al., 1980). Eotaxin $(100 \mathrm{ng} / \mathrm{ml})$ in RPMI1640 with $0.1 \%$ bovine serum albumin (BSA) was added to the lower compartment of the disposable 96 -well chemotaxis chamber (KURABO, Osaka) in a volume totaling $80 \mu$. The cell suspension $(50 \mu \mathrm{l}$ of $2 \times 106 \mathrm{cells} / \mathrm{ml})$ was added to the upper compartment of the chamber that had been precoated with BSA for 2 hours at $37^{\circ} \mathrm{C}$ in $1.5 \% \mathrm{CO} 2$. Compartments were separated by a $5-\mu \mathrm{m}$ pore size polycarbonate, polyvinylpyrrolidone-free filter. The chamber was incubated for 2 hours at $37^{\circ} \mathrm{C}$ in $1.5 \% \mathrm{CO} 2$. At the end of the incubation, the cells in the lower compartment were stained using the CyQUANT NF Cell Proliferation Assay Kit (Invitrogen, Eugene, OR).

\subsection{P38 MAP kinase assay}

Df-HL-60 clone 15 cells $(5 \times 106$ cells $/ \mathrm{ml} ; 5 \mathrm{ml})$ that had been preincubated either with medium or NAC $(5 \mathrm{mM})$ for one hour were stimulated with eotaxin $(100 \mathrm{ng} / \mathrm{ml})$ for an additional one hour. After eotaxin stimulation, the cells were further stimulated with medium or DEPs $(0.1 \mathrm{mg} / \mathrm{ml})$ for one hour. The activity of p38 MAP kinase was analyzed by a commercially available kit (p38 MAP kinase Assay Kit; Cell Signaling Technology, Inc., Danvers, MA). Cell lysates were prepared and incubated overnight with immobilized p38 MAP kinase (Thr180/Tyr182) monoclonal antibody. Kinase reaction was performed in the presence of $100 \mu \mathrm{M}$ of cold ATP and $2 \mu \mathrm{g}$ of activating transcription factor-2 (ATF-2) fusion protein. One $\mu \mathrm{g}$ of samples was separated by a $5-20 \%$ gradient SDS-PAGE and transferred to membranes. Phosphorylation of ATF-2 at Thr71 was measured by western blot using phospho-ATF-2 (Thr71) specific antibody.

\subsection{Statistical Analysis}

For in vitro studies, six independent replicate analyses were performed for each experimental condition and time point unless otherwise noted and the data were expressed as the mean \pm SD. Groups were compared using the two-way ANOVA followed by post hoc 
Dunnett's test. Statistical significance was set at $\mathrm{p}<0.05$.

\section{Results}

3.1.DEPs Induce MCP-1 and IL-8 Production in HL-60 clone 15 cells

We examined effect of DEPs in df-HL-60 clone 15 cells by cytokine antibody array method. As shown in Figure 1A, MCP-1 (C6 and D6) and IL-8 (E12 and F12) were detected as positive signals under each condition. MCP-1 levels in the DEP treated groups tended to markedly increase by 1.9-fold over those in the untreated group. IL-8 levels in the DEP treated groups tended to slightly increase by 1.1-fold over those in the untreated group. IL-1treated df-HL-60 clone 15 cells exhibited 2.2-fold and 1.5-fold increases in MCP-1 and IL-8, respectively. We examined the effect of DEPs on MCP-1 production. The concentration of MCP-1 was increased in a dose-dependent manner after treatment with DEPs $(0-0.1 \mathrm{mg} / \mathrm{ml})$ and was 6.5 -fold greater than that of the control at the zenith (data not shown).

\subsection{DEPs up-regulate NF- $\kappa B$ activation in df-HL-60 clone 15 cells}

NF- $\kappa \mathrm{B}$ activation was measured in the nuclear extracts from df-HL-60 clone 15 cells. NF- $\kappa \mathrm{B}$ activity of $1 \mu \mathrm{g}$ protein was shown in Figure 2. NF- $\kappa$ B activity was increased after stimulation with DEPs (Wild - DEP + ); in contrast, NF- $\kappa$ B activity was significantly decreased following administration of competitive oligonucleotide (Wild + DEP -, Wild + DEP + $\mathrm{X})(\mathrm{p}<0.05)$.

\subsection{MG132 inhibits DEPs-induced MCP-1 production}

We examined DEPs-induced MCP-1 production after administration of MG132 in dfHL-60 clone 15 cells.As shown in Figure 3, MCP-1 was increased after stimulation with DEPs (MG132 - DEP +); in contrast, MCP-1 was significantly decreased following administration of MG132 (MG132 + DEP -, MG132 + DEP +)(p<0.01).

\subsection{Effect of p38 MAP kinase activation on df-HL-60 clone 15 cell chemotaxis}

We examined DEPs-induced chemotaxis after administration of NAC in df-HL-60 clone 15 cells. As shown in Figure 4, cell migration was significantly increased in the DEPsstimulated clone 15 cells (NAC-DEP+) compared to media-stimulated control cells (NAC DEP -); in contrast, cell migration was significantly decreased following administration of $\mathrm{NAC}(\mathrm{NAC}+\mathrm{DEP}-)(\mathrm{p}<0.01)$

\subsection{DEPs affect $p 38$ MAP kinase (Thr180/Thr182) activity} We examined DEPs affect of p38 MAP kinase (Thr180/Thr182) activity in df-HL-60 clone 15 cells. As shown in Figure 5, levels of the phosphorylated form of the ATF-2 protein of p38 MAP kinase were greater in DEPs-treated cells (lane 2) than in untreated cells (lane 1). In contrast, ATF-2 phosphorylation levels in NAC-pretreated cells (lane 3) and in NAC + DEPstreated cells (lane 4$)$ were significantly low $(p<0.01)$, indicating that pretreatment of cells with NAC resulted in the inhibition of DEPs-induced p38 MAP kinase activation.

\section{Discussion}

We have examined a biologic response of DEPs leading to eosinophilia in bronchial asthma. To elucidate the mechanisms, an in vitro approach was used in which human eosinophilic cells were exposed to DEPs. We described in this paper the effect of DEPs on a myeloid cell line differentiated into eosinophils. We showed that DEPs induced MCP-1 and IL-8 production by up-regulating NF- $\kappa$ B activity, which is inhibited in the presence of an inhibitor of proteasomal degradation. DEPs also promoted eotaxin-induced chemotaxis in a 
p38 MAP kinase dependent manner.

The above findings indicate a mechanism that DEPs enhance inflammation by the following process. In the late stage of bronchitis due to DEPs, eosinophils are involved in neutrophil and macrophage recruitment. These cells build up and secrete eotaxin which further recruits eosinophils, leading to enhanced inflammation.

The following are caused when human peripheral blood lymphocytes are exposed to DEPs: mRNA expression of IL-8, MCP-1, and RANTES increases, eotaxin mRNA level of bronchial epithelial cells increases (Fahy et al., 2000), ICAM-1 production increases (Takizawa et al., 2003), and histamine mRNA of nasal mucosal cells increases (Terada et al., 1999). Accumulation of neutrophils, eosinophils, and macrophages occurs at the inflammation site due to DEPs. At the same time, inflammatory cytokines and chemical mediators are released from cells which developed inflammation. This sequence of events is thought to enhance inflammation. A recent study has reported neutrophil migration by IL-8 possibly leads to eosinophilia in severe asthma (Kobayashi et al., 2007). In this study, IL-8 production by eosinophils increased by $10 \%$ due to DEPs exposure. Our data may suggest the mechanism which changes the acute stage of neutrophil predominance into the late stage of the eosinophils predominance in bronchial asthma.

An increase in IL-8 and MCP-1 production is inhibited by the antagonist of MAP kinase (Fahy et al., 2000). Therefore, DEPs are thought to enhance inflammation through the activation of the MAP kinase pathway. DEPs activate the NF- $\kappa$ B activation of bronchial epithelial cells, increase IL-8 production, and stimulate the migration of neutrophils. At the same time, DEPs induce the production of the antibacterial peptide beta-defensin 2 (Nam et al., 2006). It is believed that the defense system against bacterial infection is used to repair and to remove DEPs incorporated into the body. Furthermore, unoxidized DEPs reduce IFN $\gamma$ of antigen-specific T-cells of dendritic cells, which are derived from mouse marrow, and increase IL-10. Such DEPs activate the nuclear factor-erythroid 2 (NF-E2)-related factor 2mediated signaling pathway and inhibit IL-12 production (Chan et al., 2006). Therefore, DEPs inhibit the Th1 differentiation and are thought to be involved in the shift to Th2 differentiation.

According to a recent report, when macrophages phagocytize ultra fine particles contained in DEPs, phagocytic function decreases (Lundborg et al., 2006). In addition, the dendritic cells (DCs) derived from immature monocytes are unable to differentiate into functional T-cells due to DEPs exposure (Bleck et al., 2006), suggesting possibly to a difficult state of foreign body removal. The results of our experiment showed that there was a $190 \%$ increase of MCP-1 through NF- $\kappa$ B activation due to DEPs exposure of eosinophil. The exposed eosinophils strongly affected macrophage infiltration. Furthermore, it would be interesting to examine whether or not normally functioning macrophages will mature from monocytes that accumulated in the bronchial tubes due to MCP-1, which is produced by eosinophils induced by DEP exposure.

DEPs exposure in human bronchial epithelial cells improved eotaxin gene expression (Bree et al., 2007). In this study, DEPs exposure in eosinophil also promoted eotaxin-induced chemotaxis in a p38-dependent manner. From these findings, it was found that DEP further accelerates the eosinophil infiltration by p38 MAP kinase activation of eosinophil.

\section{Figure Legends}

Figure 1. Detection of cytokines and chemokines on membrane antibody arrays by chemiluminescence. Df-HL-60 clone 15 cells $(5 \times 105$ cells $/ \mathrm{ml})$ were treated with DEPs $(0.03$ $\mathrm{mg} / \mathrm{ml})$, IL-1 (10 ng/ml), or buffer for 72 hours at $37^{\circ} \mathrm{C}$, and cytokines and chemokines present in the supernatant were determined using a RayBio Human Cytokine Antibody Array. (A) Image obtained with a CCD camera after an exposure of 90 seconds using a Light Capture 
AE-6972 imaging system. Each cytokine and chemokine was represented by duplicate spots on the membrane. G1, H1, A11 and B11 were spotted with HRP-conjugated antibody (positive control), G2 and $\mathrm{H} 2$ were spotted with bovine serum albumin (negative control). (B) Average net light intensity for each pair of cytokine spots detected on the basis of grayscale imaging.

Figure 2. Effect of DEPs on NF- $\kappa$ B activation to df-HL-60 clone 15 cells by ELISA. Df-HL60 clone 15 cells were treated with $0.1 \mathrm{mg} / \mathrm{mL}$ DEPs for 4 hours. After incubation, nuclear fractions were prepared and used for the analysis of NF- $\kappa$ B p 65 by ELISA. The results were expressed as the means $\pm \mathrm{SD}$ of six different experiments. Statistical analysis of difference was performed by two-way ANOVA. Statistically significant difference as compared to the value of the group without DEPs, $* * p<0.01$. Statistically significant difference as compared to the value of the group without DEP, $\# \# \mathrm{p}<0.01$.

Figure 3. Effect of DEPs on MCP-1 production to df-HL-60 clone 15 cells by ELISA. Df-HL60 clone 15 cells that had been preincubated with either medium or MG132 (5 nM) for one hour were cultured either with medium or DEPs $(0.1 \mathrm{mg} / \mathrm{ml})$ for 24 hours at $37^{\circ} \mathrm{C}$. The results are expressed as means \pm SD of six different experiments. Statistical analysis of difference was performed by two-way ANOVA. Statistically significant difference as compared to the value of the group without DEPs, ${ }^{* *} \mathrm{p}<0.01$. Statistically significant difference as compared to the value of the group without MG132, $\# \mathrm{p}<0.05$.

Figure 4. Effect of DEPs on p38 MAP kinase activation to df-HL-60 clone 15 cells chemotaxis. Cells were pretreated with either medium or NAC $(5 \mathrm{mM})$ for one hour and then stimulated with eotaxin $(100 \mathrm{ng} / \mathrm{ml})$ for one hour. After eotaxin stimulation, the cells were further stimulated with medium or DEPs $(0.1 \mathrm{mg} / \mathrm{ml})$ for one hour. The results are expressed as means \pm SD of six different experiments. Statistical analysis of difference was performed by two-way ANOVA. Statistically significant difference was obtained compared to the value of the group without DEPs, ${ }^{* *} \mathrm{p}<0.01$. Statistically significant difference as compared to the value of the group without NAC, $\# \# p<0.01$.

Figure 5. Effect of DEPs on $\mathrm{p} 38$ MAP kinase activation to df-HL-60 clone 15 cells by Western blot. Df-HL-60 clone 15 cells that had been preincubated either with medium or NAC $(5 \mathrm{mM})$ for one hour were stimulated with eotaxin $(100 \mathrm{ng} / \mathrm{ml})$ for an additional one hour. After eotaxin stimulation, the cells were further stimulated with medium or DEPs $(0.1$ $\mathrm{mg} / \mathrm{ml}$ ) for one hour. The lysates from df-HL-60 clone 15 cells were separated by a 5-20\% gradient SDS-PAGE and transferred to membranes. Phosphorylation of ATF-2 at Thr71 was measured by western blot using phospho-ATF-2 (Thr71) specific antibody (upper panel). The cells were cultured with medium (lane 1), DEPs (lane 2), NAC (lane 3), and DEPs and NAC (lane 4). The fold increase in amount of phospho-ATF-2 protein is indicated (lower panel). The amounts of phospho-ATF-2 protein were presented as relative to control cells (NAC DEP -)(1.0). Six identical experiments independently performed gave similar results. The results are expressed as means \pm SD of six different experiments. Statistical analysis of difference was performed by two-way ANOVA. Statistically significant difference was obtained compared to the value of the group without DEPs, $* * \mathrm{p}<0.01$. Statistically significant difference as compared to the value of the group without NAC, \#\#p<0.01.

\section{References}

Albert, C.J., Thukkani, A.K., Heuertz, R.M., Slungaard, A., Hazen, S.L., Ford, D.A., 
2003. Eosinophil peroxidase-derived reactive brominating species target the vinyl ether bond of plasmalogens generating a novel chemoattractant, alpha-bromo fatty aldehyde. 278. 8942-8950.

Amakawa, K., Terashima, T., Matsuzaki, T., Matsumaru, A., Sagai, M., Yamaguchi, K., 2003. Suppressive effects of diesel exhaust particles on cytokine release from human and murine alveolar macrophages. Experimental lung research 29. 149164.

Bleck, B., Tse, D.B., Jaspers, I., Curotto De Lafaille, M.A., Reibman, J., 2006. Diesel exhaust particle-exposed human bronchial epithelial cells induce dendritic cell maturation. 176. 7431-7437.

Bloemen, K., Verstraelen, S., Van Den Heuvel, R., Witters, H., Nelissen, I., Schoeters, G., 2007. The allergic cascade: Review of the most important molecules in the asthmatic lung. 113. 6-18.

Brauer, M., Hoek, G., Van Vliet, P., Meliefste, K., Fischer, P., Gehring, U., Heinrich, J., Cyrys, J., Bellander, T., Lewne, M., Brunekreef, B., 2003. Estimating long-term average particulate air pollution concentrations: application of traffic indicators and geographic information systems. Epidemiology (Cambridge, Mass 14. 228239.

Bree, A., Schlerman, F.J., Wadanoli, M., Tchistiakova, L., Marquette, K., Tan, X.Y., Jacobson, B.A., Widom, A., Cook, T.A., Wood, N., Vunnum, S., Krykbaev, R., Xu, X., Donaldson, D.D., Goldman, S.J., Sypek, J., Kasaian, M.T., 2007. IL-13 blockade reduces lung inflammation after Ascaris suum challenge in cynomolgus monkeys. 119. 1251-1257.

Busse, W.W., 1998. Leukotrienes and inflammation. 157. S210-213.

Chan, R.C., Wang, M., Li, N., Yanagawa, Y., Onoe, K., Lee, J.J., Nel, A.E., 2006. Prooxidative diesel exhaust particle chemicals inhibit LPS-induced dendritic cell

responses involved in T-helper differentiation. The Journal of allergy and clinical immunology 118. 455-465.

Diaz-Sanchez, D., Proietti, L., Polosa, R., 2003. Diesel fumes and the rising prevalence of atopy: an urban legend? 3. 146-152.

Fahy, O., Hammad, H., Senechal, S., Pestel, J., Tonnel, A.B., Wallaert, B., Tsicopoulos, A., 2000. Synergistic effect of diesel organic extracts and allergen Der $p 1$ on the release of chemokines by peripheral blood mononuclear cells from allergic subjects: involvement of the map kinase pathway. American journal of respiratory cell and molecular biology 23. 247-254.

Falk, W., Goodwin, R.H., Jr., Leonard, E.J., 1980. A 48-well micro chemotaxis assembly for rapid and accurate measurement of leukocyte migration. Journal of immunological methods 33. 239-247.

Fischkoff, S.A., 1988. Graded increase in probability of eosinophilic differentiation of HL-60 promyelocytic leukemia cells induced by culture under alkaline conditions. Leukemia research 12. 679-686.

Holgate, S.T., Sandstrom, T., Frew, A.J., Stenfors, N., Nordenhall, C., Salvi, S., Blomberg, A., Helleday, R., Soderberg, M., 2003. Health effects of acute exposure to air pollution. Part I: Healthy and asthmatic subjects exposed to diesel exhaust. Research report (Health Effects Institute) 1-30; discussion 51-67. Kanoh, T., Suzuki, T., Ishimori, M., Ikeda, S., Ohasawa, M., Ohkuni, H., Tunetoshi, Y., 1996. Adjuvant activities of pyrene, anthracene, fluoranthene and benzo(a)pyrene in production of anti-IgE antibody to Japanese cedar pollen allergen in mice. Journal of clinical \& laboratory immunology 48. 133-147.

Kobayashi, T., Takaku, Y., Kikuchi, I., Soma, T., Hagiwara, K., Kanazawa, M., Nagata, 
M., 2007. Eosinophils do not enhance the trans-basement-membrane migration of neutrophils. 143 Suppl 1. 38-43.

Lee, K.A., Bindereif, A., Green, M.R., 1988. A small-scale procedure for preparation of nuclear extracts that support efficient transcription and pre-mRNA splicing. Gene analysis techniques 5. 22-31.

Lopez, J.A., Newburger, P.E., Condino-Neto, A., 2003. The Effect of IFN- $\gamma$ and TNF- $\alpha$ on the Eosinophilic Differentiation and NADPH Oxidase

Activation of Human HL-60 Clone 15 Cells. Journal of Interferon \& Cytokine Research 23. 737-744.

Lundborg, M., Dahlen, S.E., Johard, U., Gerde, P., Jarstrand, C., Camner, P., Lastbom, L., 2006. Aggregates of ultrafine particles impair phagocytosis of microorganisms by human alveolar macrophages. Environmental research 100. 197-204.

Marguet, C., Dean, T.P., Basuyau, J.P., Warner, J.O., 2001. Eosinophil cationic protein and interleukin-8 levels in bronchial lavage fluid from children with asthma and infantile wheeze. 12. 27-33.

Nam, H.Y., Ahn, E.K., Kim, H.J., Lim, Y., Lee, C.B., Lee, K.Y., Vallyathan, V., 2006.

Diesel exhaust particles increase IL-1beta-induced human beta-defensin

expression via NF-kappaB-mediated pathway in human lung epithelial cells.

Particle and fibre toxicology [electronic resource] 3. 9.

Pandya, R.J., Solomon, G., Kinner, A., Balmes, J.R., 2002. Diesel exhaust and asthma:

hypotheses and molecular mechanisms of action. Environmental health

perspectives 110 Suppl 1. 103-112.

Pegorier, S., Wagner, L.A., Gleich, G.J., Pretolani, M., 2006. Eosinophil-derived cationic proteins activate the synthesis of remodeling factors by airway epithelial cells.

177. 4861-4869.

Schmid-Grendelmeier, P., Altznauer, F., Fischer, B., Bizer, C., Straumann, A., Menz, G., Blaser, K., Wuthrich, B., Simon, H.U., 2002. Eosinophils express functional IL13 in eosinophilic inflammatory diseases. 169. 1021-1027.

Takizawa, H., Abe, S., Okazaki, H., Kohyama, T., Sugawara, I., Saito, Y., Ohtoshi, T.,

Kawasaki, S., Desaki, M., Nakahara, K., Yamamoto, K., Matsushima, K., Tanaka,

M., Sagai, M., Kudoh, S., 2003. Diesel exhaust particles upregulate eotaxin gene

expression in human bronchial epithelial cells via nuclear factor-kappa Bdependent pathway. American journal of physiology 284. L1055-1062.

Terada, N., Hamano, N., Maesako, K.I., Hiruma, K., Hohki, G., Suzuki, K., Ishikawa, K.,

Konno, A., 1999. Diesel exhaust particulates upregulate histamine receptor

mRNA and increase histamine-induced IL-8 and GM-CSF production in nasal

epithelial cells and endothelial cells. Clinical and experimental allergy : journal of

the British Society for Allergy and Clinical Immunology 29. 52-59.

Xu, J., Wu, Y., He, L., Yang, Y., Moore, S.A., Hsu, C.Y., 1997. Regulation of cytokineinduced iNOS

expression by a hairpin oligonucleotide in murine cerebral

endothelial cells. Biochemical and biophysical research communications 235 .

394-397.

Yamaguchi, Y., Zhang, D.E., Sun, Z., Albee, E.A., Nagata, S., Tenen, D.G., Ackerman,

S.J., 1994. Functional characterization of the promoter for the gene encoding human eosinophil peroxidase. The Journal of biological chemistry 269. 19410-

19419. 
Figure(1)

(A)

Centrol +DEP +IL-1

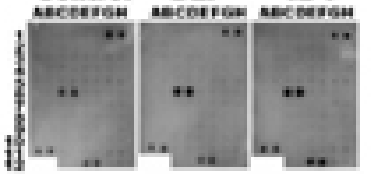

(B)

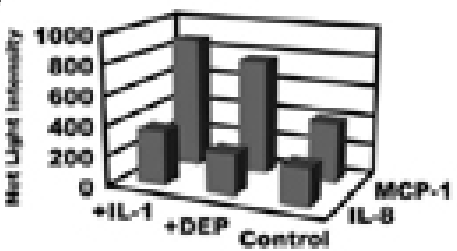

Figure(2)

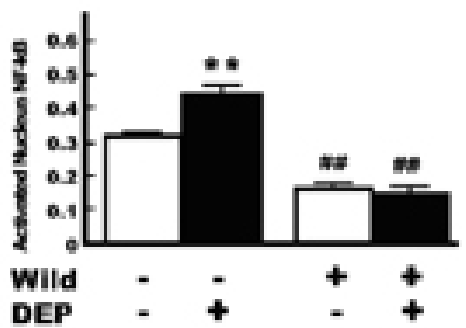

Figure2. 
Figure(3)

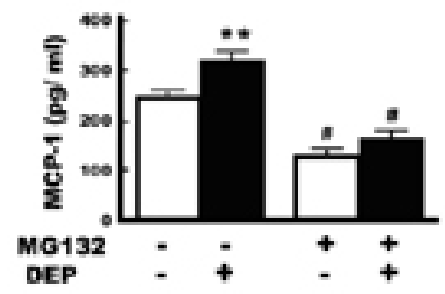

Figure(4)

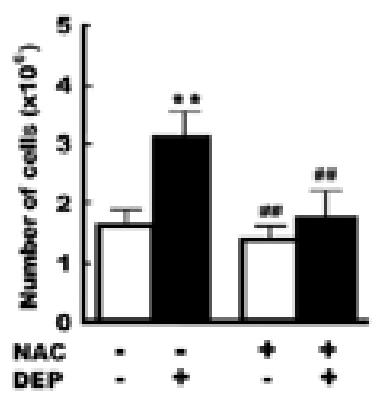

Figure 4.

Figure(5)

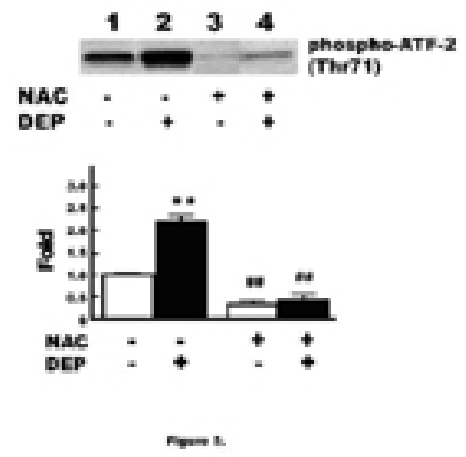

